\title{
CONSUMO, TECNOLOGIA E REDES SOCIAIS: APPS, 3D E EMOTICONS EM ANÁLISE
}

O volume 10 da revista Signos do Consumo traz no conjunto dos artigos selecionados reflexões que integram as dinâmicas impostas pelas tecnologias digitais, tanto por meio da discussão acerca dos equipamentos e das mídias quanto das lógicas impostas pelas novas formas de comunicação e de relacionamento. Reúne artigos de pesquisadores das regiões Sul, Sudeste, Centro-Oeste e Nordeste, de universidades e centros de pesquisa diversos, o que reafirma o espaço plural desta publicação.

O primeiro artigo de 2018, de autoria de Fernanda de Abreu, da Universidade Federal Fluminense, aborda a questão do live marketing e seus impactos para a publicidade. Este se posiciona como uma possibilidade de construção promocional que não se opõe à publicidade, mas, ao contrário, integra-se à complexidade e à diversidade que a digitalização trouxe ao planejamento comunicacional das marcas.

A questão da tecnologia digital, agora na versão 3D, é temática do artigo "Impressoras 3D: uma mudança na dinâmica do consumo", de autoria de Cristiano Pinheiro, Gabriela Mota, Camila Steinhaus e Mikaela de Souza, todos da Feevale de Novo Hamburgo/ RS. O texto apresenta o tema da mudança nos modos de consumir produtos e ideias a partir da ampliação do acesso às impressoras 3D, decorrente da redução dos custos de produção e do seu preço. A questão central discutida é a mudança nos processos de produção, mas também de consumo, com ênfase na customização e na imediaticidade desses processos, agora possíveis e mais acessíveis.

Stephanie Estéban, da Universidade de São Paulo, e Olga Maria Pépece, da Universidade Estadual de Maringá, apresentam o texto "Desvendando o consumo ritualístico dos bailes de debutante". O objetivo do artigo é identificar os princípios que compõem o "baile de debutante" - abordando as diferentes manifestações que envolvem os artefatos simbólicos utilizados, vestimentas, papeis sociais etc. -, bem como compreender quais os sentidos que sustentam esse ritual na contemporaneidade. Para tanto, as autoras integraram às reflexões teóricas um estudo empírico na cidade de Maringá, no Paraná.

"Usain Bolt como entidade enunciativa: a construção de sua marca pessoal no contexto das Olimpíadas de 2016” é o artigo de Rafael dos Santos Hönig, Fabiano Maggioni e Magnos Cassiano Casagrande, pesquisadores da Universidade Federal de Santa Maria/RS. Os autores problematizam as lógicas que sustentam a criação de marcas na atualidade a partir da análise do caso do atleta Usain Bolt e da construção de sua marca pessoal (me brand). A discussão teórica e a metodologia de análise estão alicerçadas na obra de Andrea Semprini acerca da marca contemporânea.

Gabriel Souza, também da Universidade Federal de Santa Maria, apresenta o texto “Totalmente Demais e as experimentações da TV Globo". A intenção do texto é identificar e analisar as inovações lançadas pela Globo por meio da telenovela Totalmente Demais, com vistas ao mapeamento das estratégias utilizadas, com foco nas dinâmicas intertextuais que favorecem a experimentação e a inclusão de conteúdos inovadores trabalhados de forma integrativa e convergente. A metodologia de análise é a semiótica greimasiana, e a pesquisa insere-se nos projetos do Grupo de Pesquisa em Comunicação Televisual da Universidade Federal de Santa Maria.

Priscila Guidini, da Universidade Metodista de São Paulo, apresenta o artigo intitulado "A comunicação com o mercado por meio de aplicativos: desafios 
e oportunidades”. O texto discute a problemática das transformações causadas pelo contexto tecnológico na busca de construir relevância para os consumidores - um grande desafio para a comunicação das organizações. Nesse sentido, o uso dos apps aponta para uma possibilidade de construção de relacionamentos, além de serem eles veículos de comunicação multimidiática privilegiados. Interessante reflexão no contexto dos usos de apps pelas empresas.

"Emoticons do Facebook: analisando a demarcação de sentimento e engajamento do consumidor pela mídia social” é o artigo de Wesley Moreira Pinheiro, da Pontifícia Universidade Católica de São Paulo. Esse texto apresenta uma análise acerca do uso de emoticons no Facebook para demarcar emoções como forma de diálogo e construção de vínculos entre as pessoas. Os resultados preliminares indiciam a dificuldade em estabelecer uma avaliação quantitativa que seja passível de mensuração quanto à intensidade das reações expressas nos emoticons, ainda que seja reconhecido o avanço significativo obtido com estes em relação à possibilidade anterior de apenas "curtir". Certamente, um caminho interessante é entender a complexidade de sentimentos envolvidos em cada clique, que se expressa na escolha de um dos seis emoticons disponíveis (incluindo o "curtir”).

Hélio Ricardo Marino Rainho, da Fundação Getulio Vargas do Rio de Janeiro, apresenta o texto “Décadence avec élégance”: do decadentismo literário à antropologia material, um olhar sobre o consumo". O autor apresenta, a partir da análise do caráter "maldito" do consumo, a investigação da relação entre sujeito e objeto no consumo de moda e estilo de vida, tendo por base duas fontes de leitura distintas: a obra Às avessas, de Joris-Karl Huysmans, e o livro de Daniel Miller, Trecos, troços e coisas. Rainho propõe a análise da personagem Jean des Esseintes, um consumidor totalmente afeito a estetização da vida, a partir da visão da cultura material de Miller, na qual os objetos são "resgatados” de sua superficialidade para uma ontologia própria que dialoga, influencia e transforma as pessoas, elevando, assim, seu status puramente objetal.

"Diretrizes para compreensão dos silenciamentos nos discursos publicitários brasileiros: o setor automotivo" é o artigo de Rogério Covaleski, professor da Universidade Federal de Pernambuco. O texto apresenta a discussão baseada nas evidências e omissões da publicidade em seu fazer que, tendencialmente, privilegia os argumentos favoráveis e omite as questões que possam prejudicar a reputação de uma marca ou produto. É um estudo teórico que incorpora pesquisa em dados secundários e que pretende compreender a lógica vigente em discursos hegemônicos confrontados com cenários de crises plurais, sejam essas adversidades de ordem material ou de ordem simbólica. O texto integra as pesquisas sobre a retórica e a ética do consumo, uma vez que evidencia lacunas importantes entre as "diretrizes" e o que o autor chamou de "silenciamentos”, especificamente no setor automotivo brasileiro.

O volume 10, número 1, da Signos do Consumo encerra a edição com duas resenhas. A primeira é do livro Da leveza: rumo a uma civilização sem peso, do filósofo francês Gilles Lipovetsky. A autora Paloma Mariano, da Universidade Estadual do Centro-Oeste, apresenta a discussão central do livro com foco no espalhamento da leveza como valor contemporâneo, com impacto em todas as áreas da vida, uma vez que passa a ser um mecanismo de organização social, além de um princípio que rege a própria realidade cotidiana. A segunda resenha, de autoria de Maria Beatriz 
Portelinha, da Escola Superior de Propaganda e Marketing, refere-se ao livro De refém a protagonista: consumo, identidade e emancipação, de Sérgio Santas. O texto discute o papel do consumo nos percursos de vida das pessoas, com ênfase no entendimento das suas influências na construção das identidades contemporâneas. A autora relaciona de modo interdisciplinar a volatilidade e o trânsito das identidades, muito articuladas pela lógica do consumo.

A todos, desejamos uma ótima leitura e um novo ano de realizações!

Clotilde Perez e Eneus Trindade

Editores 